\title{
Key Design Requirements for the High Temperature Gas- Cooled Reactor Nuclear Heat Supply System
}

The INL is a

U.S. Department of Energy National Laboratory

operated by

Battelle Energy Alliance

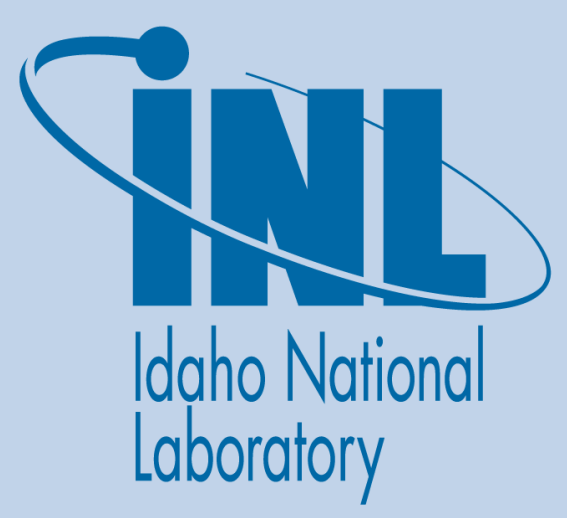

September 2010

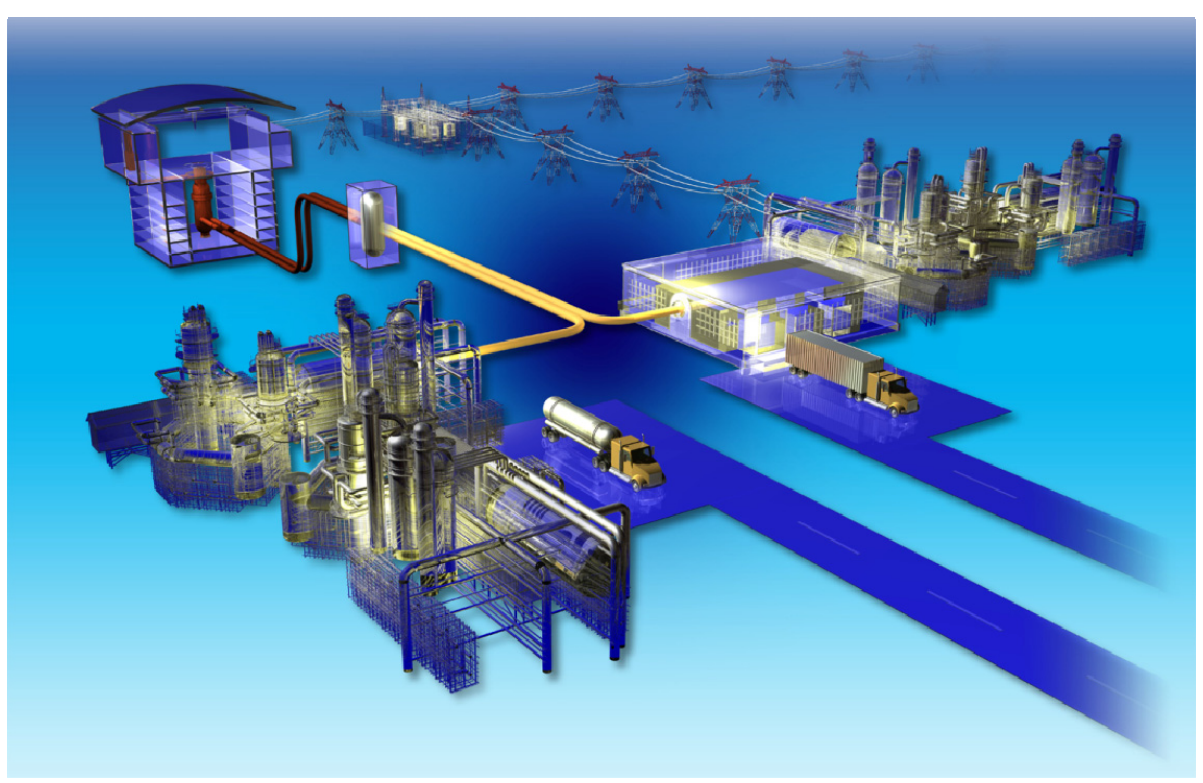




\section{DISCLAIMER}

This information was prepared as an account of work sponsored by an agency of the U.S. Government. Neither the U.S. Government nor any agency thereof, nor any of their employees, makes any warranty, expressed or implied, or assumes any legal liability or responsibility for the accuracy, completeness, or usefulness, of any information, apparatus, product, or process disclosed, or represents that its use would not infringe privately owned rights. References herein to any specific commercial product, process, or service by trade name, trade mark, manufacturer, or otherwise, does not necessarily constitute or imply its endorsement, recommendation, or favoring by the U.S. Government or any agency thereof. The views and opinions of authors expressed herein do not necessarily state or reflect those of the U.S. Government or any agency thereof. 


\section{Key Design Requirements for the High Temperature Gas-Cooled Reactor Nuclear Heat Supply System}

September 2010

Idaho National Laboratory

Next Generation Nuclear Plant Project

Idaho Falls, Idaho 83415

Prepared for the

U.S. Department of Energy

Office of Nuclear Energy

Under DOE Idaho Operations Office

Contract DE-AC07-05ID14517 

Next Generation Nuclear Plant Project

\section{Key Design Requirements for the High Temperature Gas-cooled Reactor Nuclear Heat Supply System}

INL/EXT-10-19887

September 2010

Approved by:

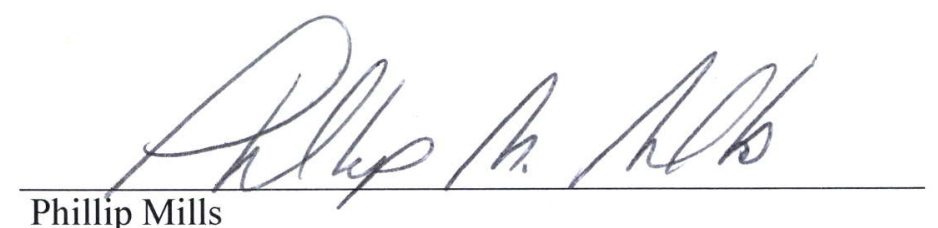

Phillip Mills

NGNP Engineering Director
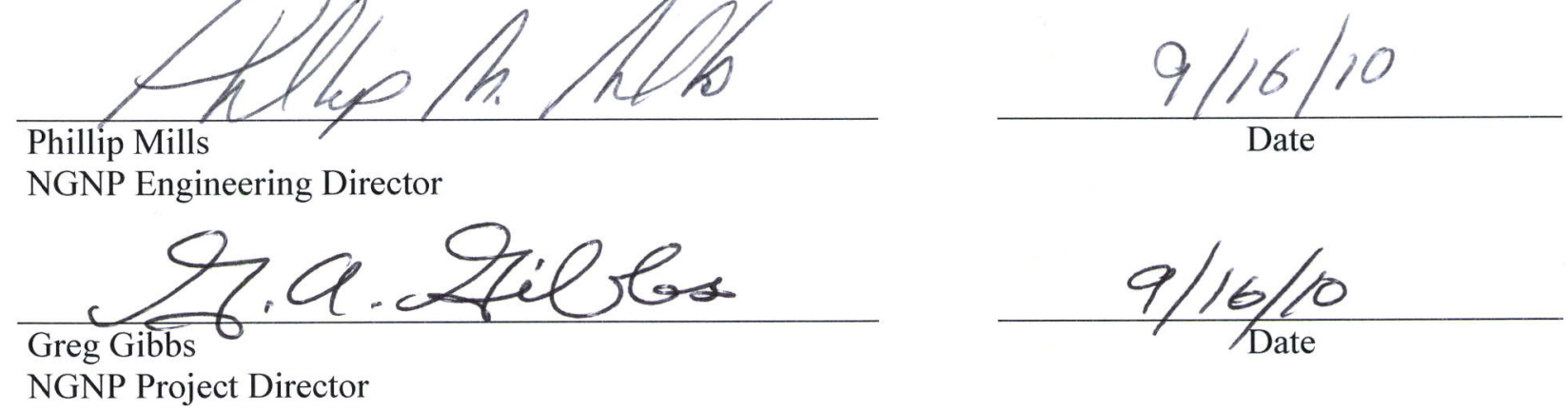

NGNP Project Director 



\begin{abstract}
Key requirements that affect the design of the high temperature gas-cooled reactor (HTGR) nuclear heat supply system as the Next Generation Nuclear Plant Project progresses through the design, licensing, construction, and testing of the HTGR based plant are summarized in this report. These requirements derive from pre-conceptual design development completed to-date by HTGR suppliers, collaboration with potential end users of the HTGR technology to identify energy needs, evaluation of integration of the HTGR technology with industrial processes and recommendations of the Next Generation Nuclear Plant Project Senior Advisory Group.

Revision 0 of this document is issued to establish an initial set of key requirements under configuration management. This will allow detailed reviews and discussions with HTGR suppliers, potential end users, and other interested parties regarding these key requirements and ultimately the establishment of the requirements set that will be used to inform the design of the HTGR nuclear heat supply system. This document will be revised as appropriate to resolve comments developed during these reviews.
\end{abstract}




\section{CONTENTS}

ABSTRACT

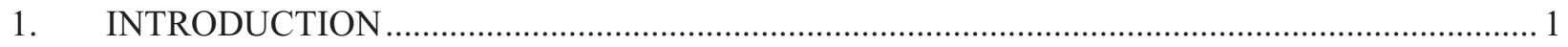

2. OBJECTIVE

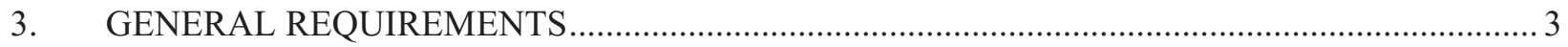

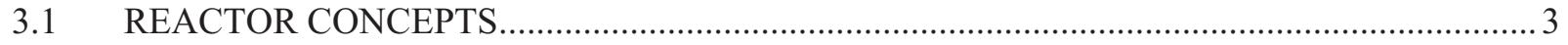

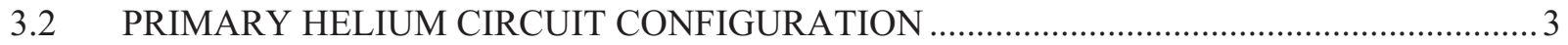

3.3 INTERFACES WITH ENERGY CONVERSION SYSTEMS ….............................................

3.4 MULTIPLE MODULE CONFIGURATIONS ..................................................................... 3

3.5 TOP LEVEL REGULATORY REQUIREMENTS.............................................................. 3

3.6 PLANT EXCLUSION AREA BOUNDARY AND EMERGENCY PLANNING ZONE ..........3

$3.7 \quad$ PLANT WORKER EXPOSURE LIMITS...................................................................... 3

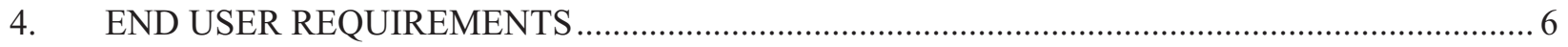

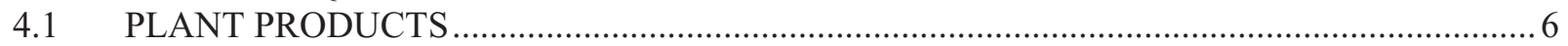

4.2 ENERGY CONVERSION SYSTEM RATINGS …........................................................ 6

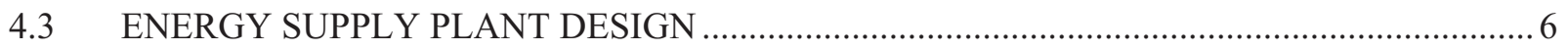

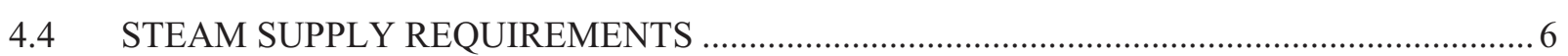

4.4.1 Steam Supply Pressure \& Temperature Margins ................................................................. 7

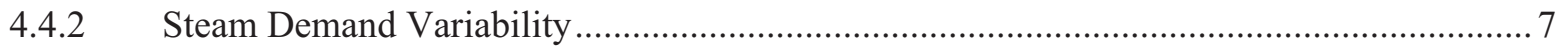

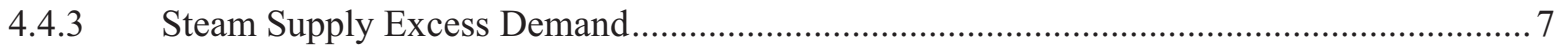

4.4.4 Steam Supply Over-Pressure Protection ................................................................. 7

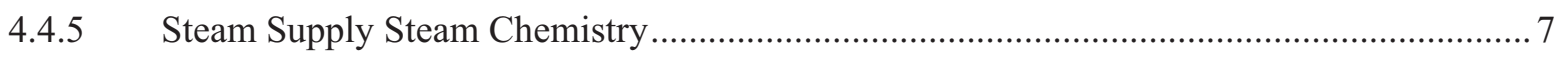

4.4.6 Steam Supply Condensate Return and Makeup .......................................................... 7

4.4.7 Return Condensate and Makeup Chemistry ............................................................... 7

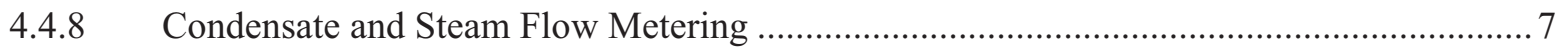

4.4.9 Steam Supply Interface Configurations ……................................................................ 7

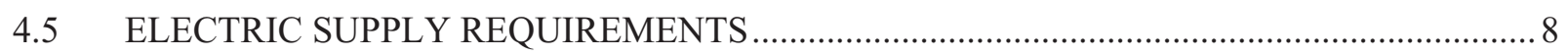

4.5.1 Electric Power Supply Interface Configurations...................................................... 8

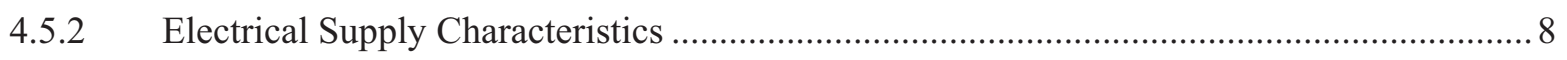

4.5.3 Electric Power Supply Power Quality.............................................................................. 8

4.6 HIGH TEMPERATURE FLUID SUPPLY REQUIREMENTS …....................................... 8

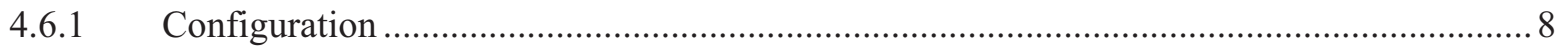

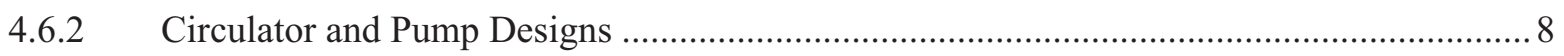

4.6.3 Secondary Fluid Circuit Purification Systems ................................................................ 8

4.6.4 High Temperature Fluid Supply Temperature Requirements ............................................ 9 
4.6.5 High Temperature Fluid Supply Physical Properties ....................................................... 9

4.6.6 High Temperature Fluid Chemistry ......................................................................... 9

4.6.7 High Temperature Fluid Supply Interface Configuration ................................................ 9

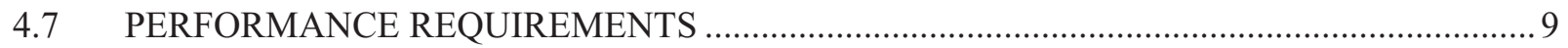

4.7.1 Normal and Emergency Demand Transients .................................................................. 9

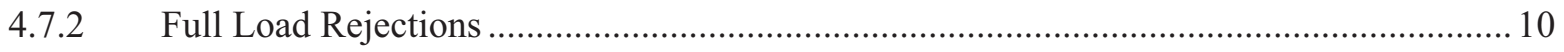

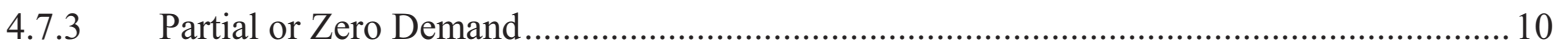

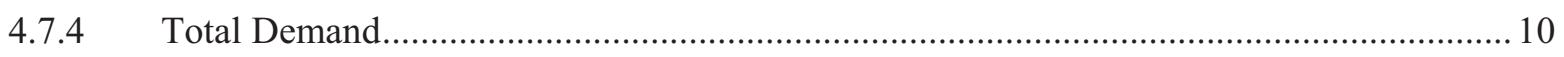

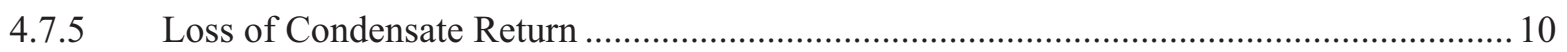

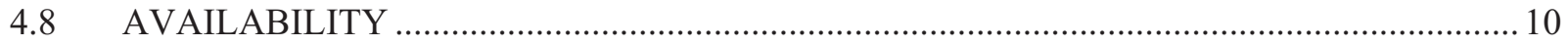

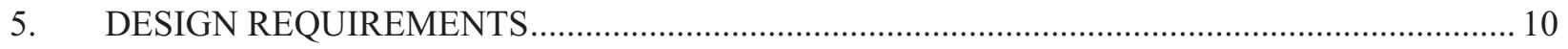

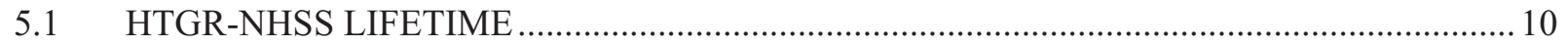

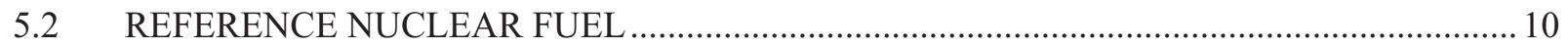

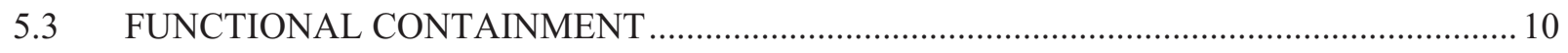

5.4 STEAM \& HIGH TEMPERATURE FLUID RADIONUCLIDE CONTENT ........................ 10

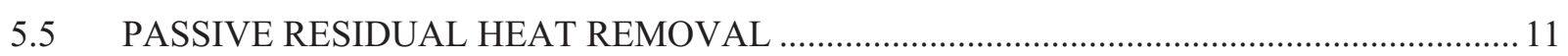

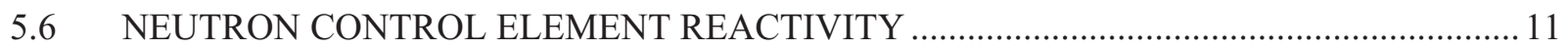

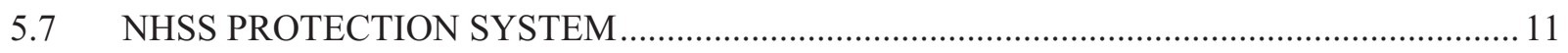

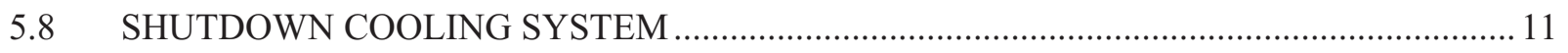

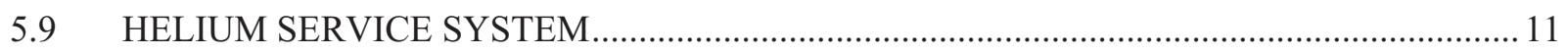

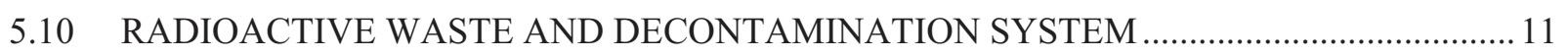

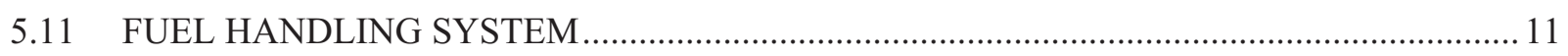

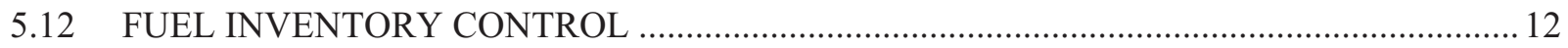

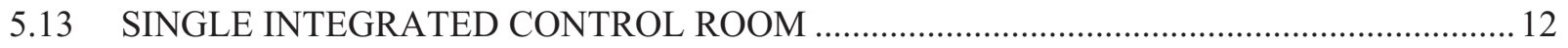

5.14 CONTROL ROOM OPERABILITY AND HABITABILITY DURING EXTERNAL EVENTS 12

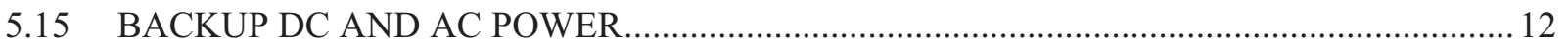

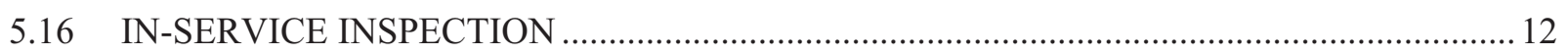

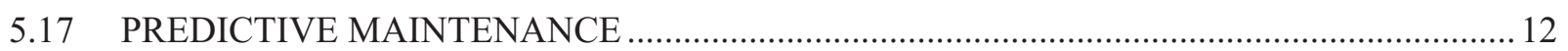

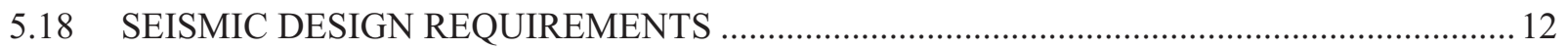

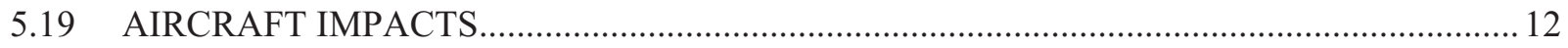

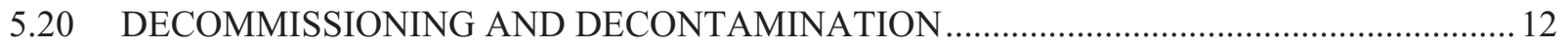

5.21 ADVANCED FABRICATION AND CONSTRUCTION TECHNIQUES ............................. 13

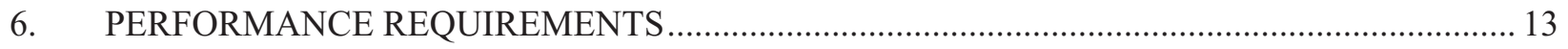

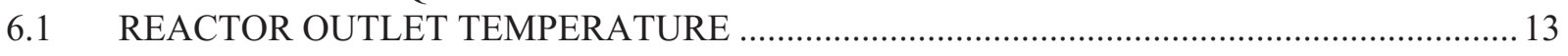

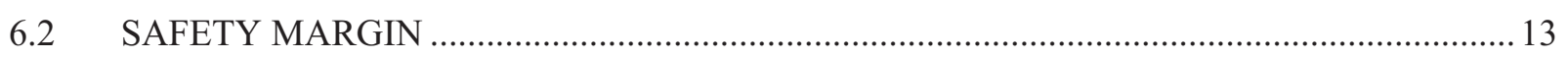




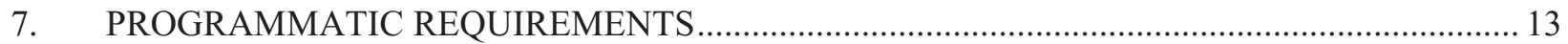

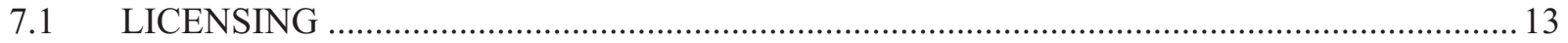

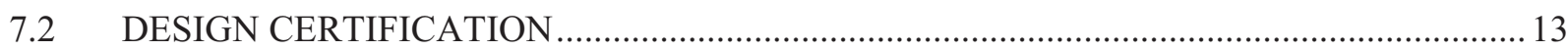

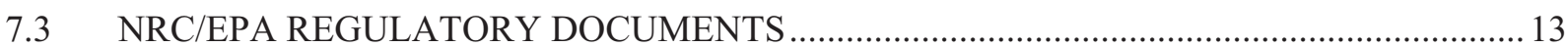

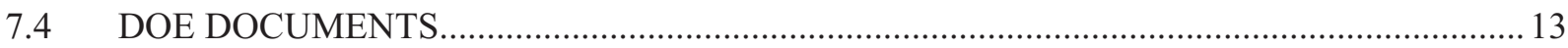

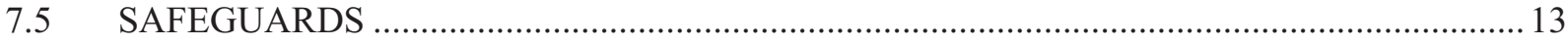

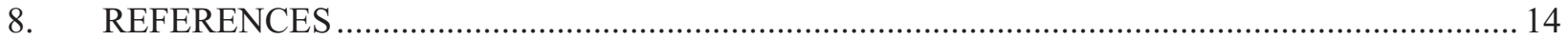

\section{FIGURES}

Figure 1. Conceptual configuration of NHSS and Energy Conversion System...................................... 2

Figure 2. Energy conversion system configurations interfacing with nuclear heat supply

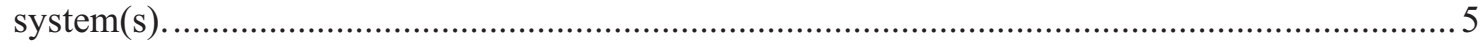




\section{Key Design Requirements for the High Temperature Gas-cooled Reactor Nuclear Heat Supply System \\ 1. INTRODUCTION}

The requirements herein apply to a high temperature gas-cooled reactor (HTGR) based nuclear heat supply system (NHSS) comprised of either a prismatic or pebble bed reactor concept, a graphite core, helium primary coolant, and necessary support systems and interfaces with an energy conversion system. Figure 1 presents a conceptual configuration of the NHSS as the energy source for energy conversion systems supplying energy to a variety of energy demands. In this configuration, the energy conversion system receives helium at the outlet temperature of the reactor, uses the high temperature helium to produce energy in forms consistent with the end user (process) needs, and returns the helium to the reactor at a lower temperature. The energy demand can include the regional electric grid, which is supplied electricity; an industrial process requiring electricity and heat via steam or other high temperature fluid; a hydrogen production facility; special applications such as recovery of hydrocarbons from oil sands and oil shale; or some combination of these. The requirements herein cover only the NHSS and its interfaces with the Energy Conversion System, but not the Energy Conversion System itself. The requirements for the Energy Conversion System will depend on the process.

These requirements are extracted from a number of sources as listed in the Reference section. The majority are resident in the NGNP Project Systems Requirements Database ${ }^{1}$, which categorizes and stores requirements from multiple NGNP Project documents prepared by the NGNP Project, HTGR suppliers, and engineering companies supporting the project. Many of these requirements were developed during the preconceptual design work conducted by the NGNP Project in FY $2007^{2}$ and then modified in discussions with the NGNP Project Senior Advisory Group ${ }^{3}$ that includes the HTGR suppliers and a nuclear power plant owner/operator. Over the last three years, the NGNP Project and the HTGR Suppliers have been reviewing the energy needs of potential end users of the HTGR technology. The NGNP Project has also performed evaluations of integration of the HTGR technology with several industrial processes, including: electricity supply to the grid; co-generation supply of steam, electricity, and high temperature gas to industrial facilities; hydrogen production; ammonia and ammonia derivative production; supply of steam or other high temperature fluids for extraction of bitumen from oil sands and enhanced oil recovery from oil shale and conversion of coal and natural gas to synthetic transportation fuels ${ }^{4}$. These interactions with the end users and the HTGR integration studies have assisted in solidifying the functional and performance requirements cited herein ${ }^{5,6}$. As this document was being prepared and reviewed by stakeholders, some modifications were made to requirements from the Systems Requirements Database and additional requirements were identified. These additions/modifications will be captured in the NGNP Project Systems Requirements Database where applicable. ${ }^{a}$

The following first identifies General Requirements for the HTGR-NHSS and then the End User Requirements developed from extensive interactions with potential end users of the HTGR technology and the evaluations of HTGR integration with several industrial processes. The remaining sections then identify design and performance requirements that derive primarily from the end user requirements and key programmatic requirements.

\footnotetext{
${ }^{a}$ Revision 0 of this document is issued to establish an initial set of key requirements under configuration management. This will allow detailed reviews and discussions with HTGR suppliers, potential end users, and other interested parties regarding these key requirements and ultimately the establishment of the requirements set that will be used to inform the design of the HTGR nuclear heat supply system. The NGNP Project will revise this document as necessary to support progression establishing these requirements.
} 


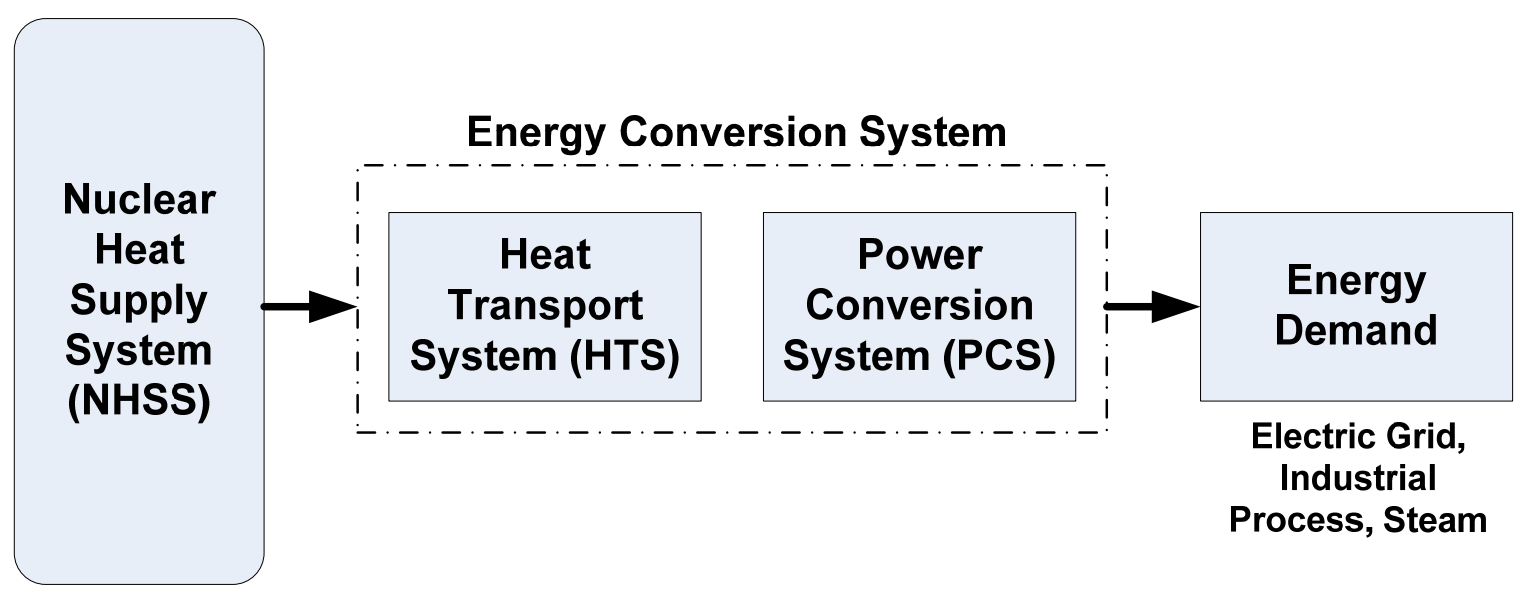

Figure 1. Conceptual configuration of NHSS and Energy Conversion System

\section{OBJECTIVE}

The objective of this document is to summarize the key requirements that are judged to have significant effect on the design of the HTGR-NHSS as the NGNP Project progresses through the design, licensing, construction, and commissioning of the HTGR based plant. This summary is not intended to be comprehensive; that is the function of the NGNP Project System Requirements database. 


\section{GENERAL REQUIREMENTS}

\subsection{REACTOR CONCEPTS}

The HTGR-NHSS shall be based on either a prismatic or pebble bed reactor concept using helium as the primary heat transport medium, TRISO - coated particle fuel, a graphite core and metallic reactor pressure vessel with dimensions and operating plant conditions that support a safety basis that does not rely on active safety related systems to maintain the reactor fuel within limits under normal, abnormal and accident conditions and to meet Top Level Regulatory Requirements under accident conditions at the Exclusion Area Boundary of the plant.

\subsection{PRIMARY HELIUM CIRCUIT CONFIGURATION}

The HTGR-NHSS primary helium circuit shall be physically separated from steam or high temperature gas supplied to the process by an intermediate heat transfer/transport system as shown in Figure 1 and Figure 2.

\subsection{INTERFACES WITH ENERGY CONVERSION SYSTEMS}

The HTGR-NHSS shall be designed to be capable of interfacing with multiple potential energy conversion configurations as shown in Figure 2.

\subsection{MULTIPLE MODULE CONFIGURATIONS}

The HTGR-NHSS shall be designed as a standalone module with the capability of being combined with other modules in a multiple module configuration with varying module configurations as shown in Figure 2 to meet energy demand requirements that exceed the rating of an individual module.

\subsection{TOP LEVEL REGULATORY REQUIREMENTS}

Fuel specifications, operating conditions, and plant shielding shall be sufficient to meet NRC and Environmental Protection Agency (EPA) exposure limits as defined by the NGNP Project in Table 1 for the public and workers under normal operation and calculated accident conditions.

3.6 PLANT EXCLUSION AREA BOUNDARY AND EMERGENCY PLANNING ZONE

The HTGR-NHSS shall be designed to achieve a plant Exclusion Area Boundary of several hundred meters ( 400 meters) and plume exposure Emergency Planning Zones equal to the Exclusion Area Boundary.

\subsection{PLANT WORKER EXPOSURE LIMITS}

The HTGR-NHSS shall limit normal maintenance exposure to no more than 50 person-REM/year per module. 
Table 1 - Top Level Regulatory Requirements

\begin{tabular}{|c|c|}
\hline \multicolumn{2}{|c|}{ NGNP Project Requirements } \\
\hline 1 & $\begin{array}{l}\text { Occupational Exposures } \leq 10 \% \text { of } 10 \text { CFR } 20 \text { Limits } \\
\text { a. TEDE } \leq 0.5 \mathrm{rem} / \mathrm{yr} \\
\text { b. Organ Dose } \leq 5 \mathrm{rem} / \mathrm{yr}\end{array}$ \\
\hline 2 & $\begin{array}{l}\text { Top Level Regulatory Criteria, including PAGs at the Exclusion Area Boundary for all events with } \\
\text { a frequency. } 5 \times 10^{-7} / \mathrm{yr}\end{array}$ \\
\hline \multicolumn{2}{|c|}{ Top Level Regulatory Requirements } \\
\hline 1 & $\begin{array}{l}10 \text { CFR 50, Appendix I, Limits for Radionuclides in Plant Effluents: } \\
\text { a. Whole Body Dose } \leq 5 \mathrm{mrem} / \mathrm{yr} \\
\text { b. Thyroid Dose } \leq 15 \mathrm{mrem} / \mathrm{yr}\end{array}$ \\
\hline 2 & $\begin{array}{l}10 \text { CFR } 20 \text { Subpart C Occupational Dose Limits: } \\
\text { a. TEDE } \leq 5 \text { rem } \\
\text { b. Organ Dose } \leq 50 \text { rem }\end{array}$ \\
\hline 3 & $\begin{array}{l}10 \text { CFR } 20 \text { Subpart D Public Dose Limits: } \\
\text { a. Annual TEDE } \leq 0.1 \text { rem } \\
\text { b. Hourly External Dose } \leq 0.002 \text { rem }\end{array}$ \\
\hline 4 & $\begin{array}{l}40 \text { CFR } 190 \text { Subpart B Environmental Standards: } \\
\text { a. Whole Body } \leq 25 \text { mrem } \\
\text { b. Thyroid Dose } \leq 75 \text { mrem } \\
\text { c. Organ Dose } \leq 25 \mathrm{mrem}\end{array}$ \\
\hline 5 & $\begin{array}{l}10 \text { CFR } 52.47 \text { Offsite Dose Limits for Licensing Basis Events: } \\
\text { a. TEDE } \leq 25 \text { rem for } 2 \text { hours at the EAB } \\
\text { b. TEDE } \leq 25 \text { rem for } 30 \text { days at the LPZ boundary }\end{array}$ \\
\hline 6 & $\begin{array}{l}\text { EPA PAGs for Radioactive Release for Public Sheltering \& Evacuation }{ }^{7} \text { : } \\
\text { a. TEDE } \leq 1 \text { rem } \\
\text { b. Thyroid Dose } \leq 5 \text { rem }\end{array}$ \\
\hline 7 & NRC Safety Risk Limits ${ }^{8}$ \\
\hline
\end{tabular}




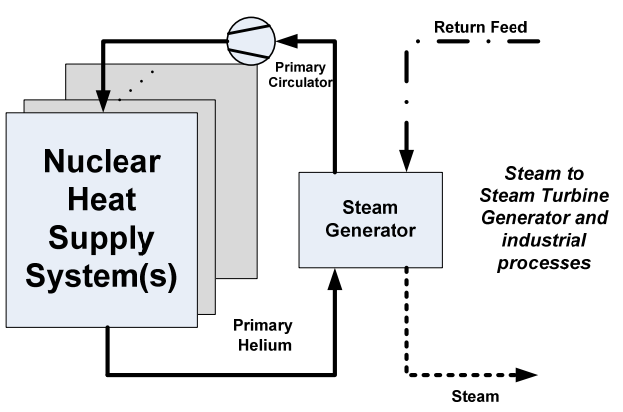

\section{Direct Steam Cycle:}

Energy is transferred from the reactor to the process using steam produced by a steam generator positioned in the primary helium circuit.

The steam can be used, for example, to generate electricity using a

Rankine cycle, supply industrial processes and for extraction of bitumen

from oil sands.

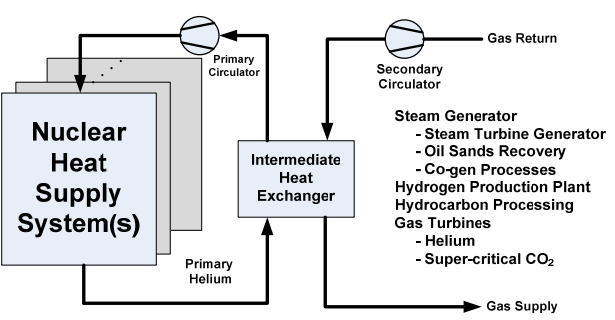

\section{Indirect Process Heat Supply:}

Energy is transferred from the reactor to the process through a primary helium to secondary fluid intermediate heat exchanger. The secondary fluids of initial designs have included helium and helium nitrogen. It is anticipated that advanced designs could use $\mathrm{CO}_{2}$ and liquid metals and molten salts. The secondary fluid can be used to supply a steam generator, support industrial processes, power gas turbines including a supercritical CO2 electric power generation system.

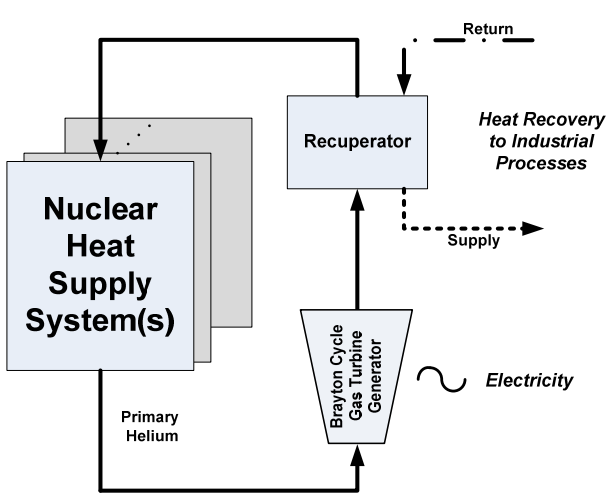

\section{Direct Brayton Gas Turbine Cycle:}

Energy is transferred in the forms of electricity and recovered heat. A Brayton cycle gas turbine generator is positioned in the primary helium circuit. The compressor of the gas turbine serves as the circulator as well as pressurizing the helium for expansion through the turbine. The recuperator recovers heat from the exhaust of the gas turbine for use in industrial processes.

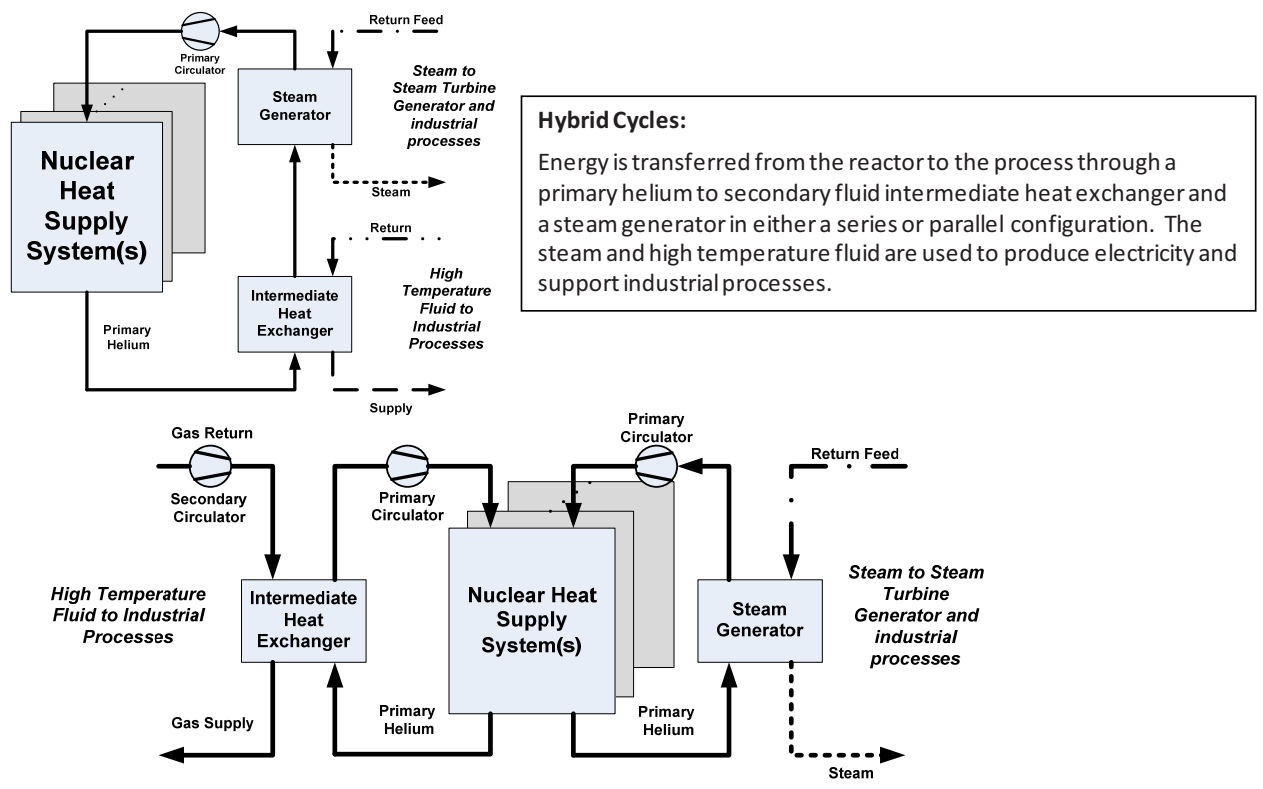

Figure 2. Energy conversion system configurations interfacing with nuclear heat supply system(s) 


\section{END USER REQUIREMENTS ${ }^{b}$}

\subsection{PLANT PRODUCTS}

The HTGR-NHSS shall have the capability to interface with energy conversion systems that supply energy in the following forms either individually or in combination:

- Electricity supplied to the regional grid and/or to support process operations

- Steam to supply steam turbine generators or for general use throughout the facility

- Process heat in the form of high temperature fluid to offset the emissions of greenhouse gases, (e.g., attendant to the burning of natural gas and waste gases in industrial processes)

Not all applications will require supply of all of these forms of energy; however, the fundamental plant design shall be capable of providing any mix of these forms as required by each specific application.

\subsection{ENERGY CONVERSION SYSTEM RATINGS}

The HTGR-NHSS shall be capable of supporting energy conversion systems with the following energy supply characteristics and demands.

\begin{tabular}{|l|l|l|l|}
\hline \multicolumn{1}{|c|}{ Plant Rating } & \multicolumn{1}{|c|}{$\begin{array}{c}\text { Supplied Steam } \\
\text { Condition }\end{array}$} & \multicolumn{1}{|c|}{$\begin{array}{c}\text { Electricity } \\
\text { Requirements }\end{array}$} & \multicolumn{1}{|c|}{$\begin{array}{c}\text { High Temperature } \\
\text { Fluid Conditions }\end{array}$} \\
\hline 250 to 6,900 MWth & $>4,000$ psig for super- & $\begin{array}{l}\text { Up to } 2,500 \mathrm{MWe} \\
\text { investigated to-date. As a }\end{array}$ & $\begin{array}{l}700 \text { to } 925^{\circ} \mathrm{C} \\
54 \text { to } 762 \mathrm{MW} \text { th }\end{array}$ \\
& $\begin{array}{l}\text { critical applications, } \\
\text { 2,500 psig for subcritical } \\
\text { applications } \\
540 \text { to } 630^{\circ} \mathrm{C}\end{array}$ & $\begin{array}{l}\text { supply to the electrical } \\
\text { grid a wide range is } \\
\text { possible depending on } \\
\text { the location. }\end{array}$ & \\
\hline
\end{tabular}

\subsection{ENERGY SUPPLY PLANT DESIGN}

The energy requirements summarized herein shall be achieved by a HTGR-NHSS using solely nuclear heat.

\subsection{STEAM SUPPLY REQUIREMENTS}

The HTGR-NHSS shall have the capability of interfacing with energy conversion systems that supply steam with the following characteristics.

\footnotetext{
${ }^{\mathrm{b}}$ For purposes of this document, the following definitions apply:

End User The entity whose Facility is being supplied the required energy in the forms specified and on whose property the HTGR energy supply is located

Purchaser The entity who purchases the energy from the Supplier, anticipated to occur via a long term energy purchase agreement

Supplier The entity who owns the HTGR energy supply

Operator The entity that is licensed to operate the HTGR energy supply

Designer The entity that performs the design of the HTGR energy supply and supports the licensing activities by the Operator
} 


\subsubsection{Steam Supply Pressure \& Temperature Margins}

The steam pressures and temperatures supplied to facility interfaces shall account for pressure and temperature drops along the facility header system to ensure that the pressures and temperatures at the end use meet requirements.

\subsubsection{Steam Demand Variability}

The HTGR plant shall be designed to meet variations in steam demand from very low to maximum demand with demand characteristics as determined by the specific application and as specified in the sections below.

\subsubsection{Steam Supply Excess Demand}

Purchaser may exercise the option of increasing the steam demand for short periods of time. The notification and periods of increased demand shall be determined in the contract between the Supplier and the Purchaser.

\subsubsection{Steam Supply Over-Pressure Protection}

Over-pressure protection shall be provided by the Supplier at the steam source.

\subsubsection{Steam Supply Steam Chemistry}

Steam supplied to the steam headers shall meet the requirements of the ASME guideline "Consensus on Operating Practices for Control of Feedwater and Boiler Water Chemistry in Modern Industrial Boilers."

\subsubsection{Steam Supply Condensate Return and Makeup}

The Purchaser shall return condensate to the HTGR plant at a rate equal to the full steam demand plus makeup as required by the HTGR plant.

This condensate shall be returned in a single header.

\subsubsection{Return Condensate and Makeup Chemistry}

The Purchaser shall provide specifications for the chemistry of the makeup and condensate returned from the steam supplied to the headers including the following as a minimum:

- $\mathrm{pH}$

- Conductivity

- TOC

- Oxygen

- Pressure

- Temperature

The Supplier shall provide any additional conditioning equipment required to meet the specification for feedwater or makeup water to the Energy Conversion System.

\subsubsection{Condensate and Steam Flow Metering}

The Supplier shall provide certified steam and condensate flow metering. Steam flow metering shall be pressure and temperature compensated.

\subsubsection{Steam Supply Interface Configurations}

The Designer shall coordinate with the Purchaser to define the specific configuration of the interfaces with the Facility steam headers. 
The following information shall be developed for each steam header and condensate return as a minimum:

Headers Pipe Diameter, Schedule, Material, Insulation and Flange Design for the supply and return

\subsection{ELECTRIC SUPPLY REQUIREMENTS}

The HTGR-NHSS shall be capable of interfacing with energy conversion systems that supply electricity to the facility and to the regional grid with the following characteristics.

\subsubsection{Electric Power Supply Interface Configurations}

- The electrical supply shall be designed to be compatible with the facility electrical distribution system and the regional grid.

- The Designer shall develop the configuration and design requirements for the electrical connection between the generator and low voltage taps on the facility distribution transformer and the regional grid transformer.

- The Supplier shall provide the transformers and power lines as required to connect with the facility distribution system and the regional grid.

\subsubsection{Electrical Supply Characteristics}

- Compatible with the U.S. electrical grid

- Distribution Voltage, KV (Facility)

- Distribution Voltage, KV (Regional Grid)

- Phase

- Frequency, hz (When islanded)

- Power Factor

- Facility Distribution Transformer, KVA

- Regional Grid Transformer, KVA

\subsubsection{Electric Power Supply Power Quality}

- The frequency and other properties and characteristics, (e.g., phase voltage imbalance) shall be as required by the regional electricity supply utility for operation on its electrical system.

- Power factor correction shall be provided by the Supplier.

\subsection{HIGH TEMPERATURE FLUID SUPPLY REQUIREMENTS}

The HTGR-NHSS shall be capable of interfacing with energy conversion systems that supply high temperature fluid via a Secondary Fluid Circuit to selected processes in the facility.

\subsubsection{Configuration}

The Secondary Fluid Circuit shall be isolated from the HTGR-NHSS Primary Helium Circuit.

\subsubsection{Circulator and Pump Designs}

The working fluid shall be compatible with standard circulator and pump designs.

\subsubsection{Secondary Fluid Circuit Purification Systems}

A means to remove corrosion products and foreign objects shall be positioned in the secondary circuit prior to entering the circulators or pumps. If required the Purification system shall also remove radionuclides transported or activated from the Primary Helium Circuit, (e.g., tritium). 


\subsubsection{High Temperature Fluid Supply Temperature Requirements}

Supply Temperature at Header, 700 to $925^{\circ} \mathrm{C}$

Return Temperature at Header, 325 to $520^{\circ} \mathrm{C}$

\subsubsection{High Temperature Fluid Supply Physical Properties}

The working fluid shall be compatible with the materials of construction in the HTGR-NHSS

Primary Helium and Secondary Fluid Circuits at all anticipated normal and abnormal operating conditions. The Designer shall provide suggested ranges for fluid physical properties based on compatibility with the designs and materials of construction of the Primary Helium and Secondary Fluid Circuits.

\subsubsection{High Temperature Fluid Chemistry}

The Designer and Purchaser shall determine the required fluid chemistry conditions to satisfy the HTGR-NHSS, the Secondary Circuit and the process requirements to include as a minimum:

- Oxygen [upper and lower limits TBD]

- Nitrogen $<[\mathrm{TBD}]^{\mathrm{c}}$ ppm

- Moisture [upper and lower dew point TBD]

- Hydrogen $<$ [TBD] ppm

- Carbon Dioxide $<$ [TBD] ppm

\subsubsection{High Temperature Fluid Supply Interface Configuration}

The Designer shall coordinate with the Purchaser to define the specific configuration of the interfaces with the process. The following information shall be developed for interface as a minimum:

Pipe Diameter, Schedule; Material; Insulation \& Flange for the supply and return

\subsection{PERFORMANCE REQUIREMENTS}

\subsubsection{Normal and Emergency Demand Transients}

When operating at power, the HTGR Plant shall be capable of responding to the following process transients without interruption or degradation of supply:

- Steam Headers

Step Change: $\pm 10 \%$

Maximum rate of change: $20 \%$ / min decreasing

Maximum rate of change: $20 \% / \mathrm{min}$ increasing

- Electric Power

Step Change: $\pm 10 \%$

Maximum rate of change: $10 \mathrm{MWe} / \mathrm{min}$ decreasing

Maximum rate of change: $10 \mathrm{MWe} / \mathrm{min}$ increasing

- High Temperature Fluid

Step Change: $\pm 10 \%$

Maximum rate of change: $20 \% /$ min decreasing

Maximum rate of change: $20 \%$ / min increasing

\footnotetext{
${ }^{\mathrm{c}}$ Items in brackets [ ] are representative; the final values will be established as the HTGR design progresses and/or HTGR based plant designs are developed for specific applications.
} 


\subsubsection{Full Load Rejections}

The Plant shall be capable of accepting a full load rejection from either steam, electrical or high temperature gas demand.

\subsubsection{Partial or Zero Demand}

Plant shall be able to accept zero steam flow demand and/or zero power demand, and/or zero high temperature gas demand. If all demand is lost temporarily the HTGR-NHSS plant shall remain capable of meeting demand as it is restored within a maximum time period to be supplied by the Designer.

\subsubsection{Total Demand}

Plant shall be capable of accommodating coincident average steam, electrical and high temperature gas demand.

\subsubsection{Loss of Condensate Return}

Plant shall be capable of operating with zero condensate return from Purchaser for 2 full power days.

\subsection{AVAILABILITY}

The average required supply of steam to the steam headers, high temperature gas to the gas headers, and electrical power generation to the electrical interconnections shall be available $100 \%$ of the time (24 hours a day, 7 days a week, 365 (366 in leap years) days per year). The N-x ${ }^{\mathrm{d}}$ availability requirements for the plant will vary according to the specific application. The most stringent identified to-date requires meeting the availability requirements with two of the nuclear heat supply modules out of service.

\section{DESIGN REQUIREMENTS}

\subsection{HTGR-NHSS LIFETIME}

The HTGR-NHSS shall have a plant design lifetime of 60 years (calendar).

\subsection{REFERENCE NUCLEAR FUEL}

Reference fuel shall be Tri-Isotopic (TRISO) coated particle fuel, LEU-based (UCO or UO2) with an enrichment limited to $<20.0 \%$ (in mass) and with a peak burn-up limited to $20 \%$ fissions per initial metal ion (FIMA).

\subsection{FUNCTIONAL CONTAINMENT}

The HTGR-NHSS shall apply the concept of a "functional containment". The functional containment is comprised of the kernel and coatings of the TRISO coated fuel particles, the fuel matrix and fuel element graphite, the primary circuit, and the reactor building. Each of these barriers contributes to limiting the release of radionuclides to the environment to meet the NGNP Project top level radiological criteria as defined in Table 1.

\subsection{STEAM \& HIGH TEMPERATURE FLUID RADIONUCLIDE CONTENT}

Methods shall be developed and implemented to control the concentrations of radionuclides in steam and high temperature fluids produced by the HTGR such that the levels of radionuclide that could be transported from the primary helium circuit or activated by exposure to the helium

\footnotetext{
${ }^{d} \mathrm{~N}$ is the number of HTGR-NHSS modules in the plant, $\mathrm{x}$ is the number that could be out of service for which the availability requirements must be met
} 
primary circuit do not exceed those that appear in steam and high temperature fluids produced by non-HTGR energy sources, (e.g., the burning of natural gas or waste gases).

\subsection{PASSIVE RESIDUAL HEAT REMOVAL}

The HTGR-NHSS shall be designed to provide passive residual heat removal to the environment that maintains fuel temperatures and core and plant structures, including concrete, within acceptable limits when neither the Primary Helium circulator nor the Shutdown Cooling System is available under normal, abnormal and accident conditions, (i.e., the nuclear system safety basis shall not depend on active cooling systems during design basis accident (DBA) conditions).

\subsection{NEUTRON CONTROL ELEMENT REACTIVITY}

The neutron control elements shall be designed to provide sufficient negative reactivity to shut down the reactor and maintain it in subcritical condition for any state while compensating for the worst positive reactivity insertion.

\subsection{NHSS PROTECTION SYSTEM}

The NHSS Protection System shall maintain plant parameters within acceptable limits established for Design Basis Accidents.

\subsection{SHUTDOWN COOLING SYSTEM}

The HTGR-NHSS shall include a Shutdown Cooling System or equivalent to transport core residual and decay heat from the reactor system to the environment when the reactor system is shutdown and the Primary Helium circulator is not operational. The Shutdown Cooling System or equivalent shall be operational whether the Helium Primary Circuit is pressurized or depressurized and during refueling, maintenance and repair activities.

\subsection{HELIUM SERVICE SYSTEM}

A Helium Service System shall be provided to maintain the Primary Helium Circuit inventory, store helium during depressurizations, provide backup supply of helium, and remove impurities including dust, oxidants, and radionuclides from the Primary Helium Circuit

\subsection{RADIOACTIVE WASTE AND DECONTAMINATION SYSTEM}

A Radioactive Waste and Decontamination System shall be provided for the following functions:

- Monitoring, collecting and processing radioactive (or potentially radioactive) liquid and gaseous wastes, including various forms of solid waste generated within the plant.

- Storing radioactive (or potentially radioactive) liquid and gaseous wastes, including various forms of solid waste generated within the plant.

- Providing equipment to remove radioactive surface contamination from components, as necessary, to facilitate control and minimize migration of radioactive contamination and to limit personnel exposure to radionuclides.

- Ensuring that all radioactive wastes generated within the facility shall be collected, monitored, treated, and processed onsite prior to shipment offsite.

\subsection{FUEL HANDLING SYSTEM}

The HTGR-NHSS shall include a Fuel Handling System to remove and replace fuel from the reactor core, prepare new fuel for use in the reactor core and store spent fuel. 


\subsection{FUEL INVENTORY CONTROL}

The HTGR-NHSS shall incorporate Nuclear Fuel Inventory Control design features facilitating implementation of material control and accounting procedures that are sufficient to enable the operating organization to account for the special nuclear material in its possession.

\subsection{SINGLE INTEGRATED CONTROL ROOM}

The HTGR-NHSS design shall permit the operators to take control of multiple modules including support processes from within a single integrated control room using the manual mode at any time for conditions of all NHSS in operation, one or more modules in refueling, one or more modules under construction, one or more modules being decommissioned.

\subsection{CONTROL ROOM OPERABILITY AND HABITABILITY DURING EXTERNAL EVENTS}

The control room shall remain operable and capable of occupation during design basis events.

\subsection{BACKUP DC AND AC POWER}

A Direct Current (DC)/Uninterruptible Power Supply (UPS) System shall provide a stored energy source for the all plant DC loads. Redundant sources of reliable $\mathrm{A} / \mathrm{C}$ power shall be provided to support all key plant $\mathrm{A} / \mathrm{C}$ loads

\subsection{IN-SERVICE INSPECTION}

The HTGR-NHSS design shall provide access to the primary and secondary loop pressure boundary to permit In-Service Inspection as required by appropriate sections of the American Society of Mechanical Engineers (ASME) Boiler and Pressure Vessel (B\&PV) Code.

\subsection{PREDICTIVE MAINTENANCE}

The HTGR-NHSS design shall include provisions for monitoring equipment status, configuration, and performance and for detecting and diagnosing malfunctions as a basis for predictive maintenance plans and decision making.

\subsection{SEISMIC DESIGN REQUIREMENTS}

The HTGR-NHSS shall be designed to withstand seismic events to the following requirements:

The reference safe shutdown earthquake (SSE) shall have an horizontal peak ground acceleration (PGA) of $[0.3 \mathrm{~g}]$.

The minimum level at which a shutdown is required to evaluate the condition of the plant following an earthquake shall be [0.1g] PGA.

A seismic margin assessment shall be performed to demonstrate that there is seismic margin in the HTGR-NHSS beyond the design level SSE. The seismic margin earthquake used in the seismic margin assessment process shall be the NUREG/CR-0098 median shape curve anchored to a $[0.5 \mathrm{~g}]$ PGA.

\subsection{AIRCRAFT IMPACTS}

HTGR-NHSS plant shall be designed and constructed with consideration of aircraft impacts, as required by NRC requirements in 10 CFR 50.150 .

\subsection{DECOMMISSIONING AND DECONTAMINATION}

The design of the NGNP shall incorporate features consistent with decommissioning and decontamination best practices. 


\subsection{ADVANCED FABRICATION AND CONSTRUCTION TECHNIQUES}

Advanced techniques, such as the use of factory or field-fabricated and assembled modules containing portions of systems and/or structures, shall be utilized (as appropriate) to reduce erection costs and schedule risks and to enhance quality control.

The design of buildings and equipment shall facilitate plant construction and the installation, repair, and replacement of equipment.

\section{PERFORMANCE REQUIREMENTS}

\subsection{REACTOR OUTLET TEMPERATURE}

The HTGR-NHSS reactor gas outlet temperature shall be in the range of $750^{\circ} \mathrm{C}$ to $950^{\circ} \mathrm{C}$. The HTGR-NHSS shall be designed for operation at the highest temperature achievable for the reactor core design (i.e., pebble bed, the prismatic cores) and to satisfy required safety margins.

\subsection{SAFETY MARGIN}

The core design shall result in a self-consistent set of parameters (e.g., power density, core delta $\mathrm{T}$, reactivity temperature coefficient) and material choices (e.g., fuel, graphite, core barrel, reactor vessel) that demonstrate adequate safety margin in satisfying the Top Level Regulatory

Requirements at the EAB (see Sections 3.6 and 3.7) when uncertainties in these parameters and in the associated calculation methods (typically at $95 \%$ confidence) are explicitly accounted.

\section{PROGRAMMATIC REQUIREMENTS}

\subsection{LICENSING}

The HTGR-NHSS shall be licensable by the US-NRC.

\subsection{DESIGN CERTIFICATION}

The HTGR-NHSS shall be designed to support certification through the 10 CFR 52 process for multiple energy conversion system configurations and process energy demands. In this regard the design interface requirements for the NHSS shall be developed and clearly decribed for the reference configurations identified in Figure 2 (e.g., transients, accidents, interfaces).

\subsection{NRC/EPA REGULATORY DOCUMENTS}

The applicability of NRC/EPA Regulatory Documents to the HTGR plant design shall be determined through regulatory gap analyses to be performed as part of the NGNP Project Licensing Plan of NGNP Project Regulatory Affairs.

\subsection{DOE DOCUMENTS}

The applicability of DOE Documents will be established in the Terms \& Conditions of the NGNP Project Public-Private Partnership.

\subsection{SAFEGUARDS}

The design of the HTGR shall comply with:

- 10 CFR 73.55, Requirements for physical protection of licensed activities in nuclear power reactors against radiological sabotage

- $\quad 10$ CFR 73.67, Licensee fixed site and in-transit requirements for the physical protection of special nuclear material of moderate and low strategic significance

- 10 CFR 75, Safeguards on Nuclear Material-Implementation of US/IAEA Agreement

- INFCIRC/57, The Text of the Agreement for the Application of Agency Safeguards to United States Reactor Facilities, and INFCIRC/540, Model Protocol Additional to the 
Agreements(s) Between State(s) and the International Atomic Energy Agency for the Application of Safeguards

- Security Assessment, "High Assurance Evaluation and Mitigative Measures Evaluation" per NUREG-800 Sections 13.6.4

- $\quad \mathrm{NRC}$ requirements for the control and accounting of special nuclear material including 10 CFR 74.19, Recordkeeping

\section{REFERENCES}

1. Idaho National Laboratory, Next Generation Nuclear Plant System Requirements Manual, INL/EXT-07-12999, Rev. 3, September 2009

2. Idaho National Laboratory, Next Generation Nuclear Plant Pre-Conceptual Design Report, INL/EXT-07-12967, Rev. 1, November 2007

3. NGNP Project Senior Advisory Group Meeting Minutes, "Next Generation Plant Project, Senior Advisory Group Meeting, Reference Configuration, Crystal City, VA, October 28, 2008," Rev. 1 of Minutes, dated January 28, 2009

4. Idaho National Laboratory, Integration of High Temperature Gas-Cooled Reactors into Industrial Process Applications, INL/EXT-09-16942, Rev. 1, February 2010

5. MPR \& Associates, Survey of HTGR Process Energy Applications, MPR-3181, Rev. 0, May 2008

6. Idaho National Laboratory, End User Functional and Performance Requirements HTGR Energy Supply to Industrial Processes, INL/EXT-10-19808, September 2010

7. EPA, 1992, "Manual of Protective Action Guides and Protective Actions for Nuclear Incidents," EPA-400-R-92-001, Environmental Protection Agency, May 1992

8. U.S. NRC, 1986, "Safety Goals for the Operations of Nuclear Power Plants: Policy Statement," 51 Federal Register 30028, August 21, 1986 